\title{
Exposure of married women to spousal violence: A community-based study in Eastern Turkey
}

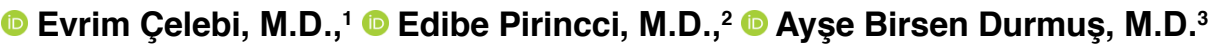

${ }^{1}$ Department of Midwifery, Fırat University Facuty of Health Sciences, Elazığ-Turkey

${ }^{2}$ Department of Public Health, Fırat University Faculty of Medicine, Elazığ-Turkey

${ }^{3}$ Fırat University Health Services Vocational High School, Elazığ-Turkey

\begin{abstract}
BACKGROUND: Violence against women deprives women of their rights to enjoy equality, security, dignity, self-worth and fundamental freedoms and devalues them; is one of the most significant social facts that force women to exist at a lower social level than men and constitute a significant obstacle to the formation of healthy societies. This study was conducted to determine the status of exposure to spousal violence of 15 years and older married women living in the city center.

METHODS: Family health centers in Elazig Province were visited and 792 married women were selected from the related records by systematic sampling. As a data collection tool, a questionnaire form was used. The questionnaire consists of two parts. In the first part, participants were asked about demographic characteristics such as age, gender, education level, and profession, while in the second part, questions were asked to determine the extent of exposure to violence. Questionnaires were filled out using interview technique by making home visits.
\end{abstract}

RESULTS: It has been found that the low level of education of the wife and her spouse, perception of the economic situation of the family as being bad, and the fact that the woman does not work in an income-generating business can be an important factor in exposing to both physical violence and economic violence by her husband.

CONCLUSION: Conclusion: Rate of exposure to spousal violence is high in married women living in the city center of Elazig Province. Education and services should be provided for solving the problem at individual, familial, and social levels.

Keywords: Economic violence; emotional violence; physical violence; sexual violence; spousal violence.

\section{INTRODUCTION}

Violence, nowadays being a global problem, can affect almost every segment of society with its different dimensions. Violence according to the definition of the World Health Organization (WHO) is; the intentional use of physical force or power, threatened or actual, against oneself, another person, or against a group or community, that either results in or has a high likelihood of resulting in injury, death, psychological harm, maldevelopment, or deprivation. ${ }^{[1]}$

Domestic violence is the most common type of violence in the society, and violence against women is the most visible aspect of domestic violence. ${ }^{[2]}$ In all countries and societies with different levels of development violence against women is in daily life in different forms. Statistics show that violence against women is a phenomenon that is found all over the world. ${ }^{[3]}$ Violence against women deprives women of their rights to enjoy equality, security, dignity, self-worth and fundamental freedoms and devalues them; is one of the most significant social facts that force women to exist at a lower social level than men and constitute a significant obstacle to the formation of healthy societies. ${ }^{[4-6]}$ Violence against women is the leading cause of disability and death for women. This violence also leads to economic loss as a result of the increase in the frequency of women's job loss and health care

Cite this article as: Çelebi E, Pirincci E, Durmuş AB. Exposure of married women to spousal violence: A community-based study in Eastern Turkey.

Ulus Travma Acil Cerrahi Derg 2022;28:69-77.

Address for correspondence: Evrim Çelebi, M.D.

Fırat Üniversitesi Sağlık Bilimleri Fakültesi, Ebelik Bölümü, Elazığ, Turkey

Tel: +90 424 - 2379139 E-mail: ecelebi@firat.edu.tr

Ulus Travma Acil Cerrahi Derg 2022;28(I):69-77 DOI: 10.14744/tjtes.2020.470I2 Submitted: 07.07.2020 Accepted: 0I. 10.2020

Copyright 2022 Turkish Association of Trauma and Emergency Surgery 
applications. The widespread violence against women is an important determinant of women's health and is a serious public health problem due to the acute and chronic effects negatively affecting women's health and consequences those can lead to women's death. ${ }^{[-11]}$ For most women who are subjected to violence, this violence is not an isolated, singular phenomenon; it is part of chronic abuse, aggression, maltreatment pattern, and women are exposed to multidimensional, multiple violence and abuse. Research has shown that physical violence is usually accompanied by psychological violence and that sexual violence is also experienced at rates ranging from one third to half of the cases. ${ }^{[12]}$

Violence is often occurs as various violent behaviors that man implements to dominate the woman influenced by the dominant male ideology that usually shapes social rules, and is used as a means of proving an authority and maintaining the relationship of sovereignty. ${ }^{[13]} \mathrm{WHO}$ has defined spousal violence as whatever behavior leads to physical, psychological, or sexual harm in a close relationship. ${ }^{[I]}$ One of the most important characteristics of spousal violence is that it is inherited from generation to generation. Violence negatively affects the psychological conditions of witnesses, and notably the psychosocial development of children, not just the victim. This shows how large the size of the situation is. Another important feature of spousal violence is that the applied violence takes place in a circle. ${ }^{[14,15]}$ International investigations have shown that actors of violence are women's spouses/partners, or family members, and provide evidence of the prevalence of violence against women. In the report published by the $\mathrm{WHO}$, it has been stated that at any point in the life of one of every three females, physical and sexual violence is inflicted by a spouse or close partner. In the same report Africa, in the Eastern Mediterranean and Southeast Asia regions about $37 \%$ of women have suffered physical and/ or sexual violence throughout their lives. This was followed by the Americas at 30\%, Europe at $25.4 \%$, and the East Pacific at $24.6 \%{ }^{[16]}$ In a similar manner results of the Study of Domestic Violence against Women in Turkey show that $37.5 \%$ of women have experienced physical or sexual violence at least once in their lifetime. ${ }^{[17]}$

This research was conducted to determine the influencing factors and the status of exposure to spousal violence of married women aged 15 and over living in the city center of Elazığ Province in eastern Turkey.

\section{MATERIALS AND METHODS}

\section{Study Design, Sample, and Setting}

This descriptive cross-sectional study was conducted with 15-year-old and over married women living in Elazig Province, located in Eastern Anatolia. In this study, the number of married women aged 15 years and over was 79295 . When the size of the sample is decided, $n=N t^{2} p q / d^{2}(N-I)+t^{2} p q$ formula is used. ${ }^{[18]}$ The probability of occurrence was $p=25 \%$, and $d=0.03$ ( $95 \%$ confidence interval $[\mathrm{Cl}])$. The sampled persons were selected by systematic sampling from the existing records in all family practice centers in Elazig Province center. Each family practice center area was represented in the sample according to its population ratio. A total of 792 women were selected and 760 of them were reached (The response rate of the study is $95.9 \%$ ). As a data collection tool, a questionnaire form which was prepared by researchers using related literature was used. The questionnaire consists of two parts. In the first part, participants were asked about demographic characteristics such as age, gender, education level, profession, while in the second part, questions were asked to determine the extent of exposure to violence. The questionnaire form was distributed by house visits and collected after 15-20 min. Verbal consent was taken from each women before the interview. The criterion of being prepared for the study group is to be married women and 15 years and over. Exclusion from study criteria; having a physical illness that cannot be cooperated, not accepting the interview. The research was conducted between April and June 2015.

\section{Statistical Analysis}

The data obtained in the study were evaluated in the Statistical Package for the Social Sciences version 22. Results are given as number, percentage, mean, and standard deviation. Chi-square test was used to compare categorical variables. In comparisons, values of $p<0.05$ were considered statistically significant. Logistic regression analysis was performed for variables that were related to violence in the Chi-square test $(p<0.05)$. They were compared to women who did not suffer from violence for risk factors (violent: I, non-violent: 0). Odd ratio $(\mathrm{OR})$ and $95 \% \mathrm{Cl}$ were calculated for each categorical variable.

\section{Ethical Considerations}

Before initiating the study, participants were informed about purpose of the study, methodology and techniques, and consent was taken. This study was reviewed and approved by the University of Firat Ethics Committee. The study was conducted in accordance with the Principles of the Helsinki Declaration.

\section{RESULTS}

The mean age of the women surveyed is $35.72 \pm 10.84$ years. The mean age of the spouses was $39.87 \pm 11.64$ and the age difference between them was $4.42 \pm 3.85$ years. About $38.0 \%$ of the women and $35.9 \%$ of the spouses are primary school graduates. While $78.7 \%$ of the women are not working, the rate of the spouses working in an income-generating job is $97.5 \%$. About $\mathbf{8 2 . 9 \%}$ of the women who participated in the survey stated that they were exposed to verbal/emotional violence; $51.5 \%$ to physical violence, $47.6 \%$ to economic violence, and $39.7 \%$ to sexual violence (Table I). 
Table 2 shows the distribution of physical violence suffered by women according to their demographic characteristics. Women over 30 years of age, women who have more than 6 years of age difference with their husbands, women who and

Table I. Types of violence that women are exposed to and their frequency distribution

\begin{tabular}{lcccccc}
\hline Type of violence & \multicolumn{4}{c}{ Exposure to violence } \\
\cline { 2 - 4 } & \multicolumn{2}{c}{ Yes } & & \multicolumn{2}{c}{ No } \\
\cline { 2 - 4 } \cline { 5 - 7 } & $\mathbf{n}$ & $\%$ & & n & $\%$ \\
\hline Physical violence & 384 & 51.5 & 360 & 48.5 \\
Verbal/emotional violence & 624 & 82.9 & 129 & 17.1 \\
Sexual violence & 283 & 39.7 & 430 & 60.3 \\
Economic violence & 345 & 47.6 & 380 & 52.4 \\
\hline
\end{tabular}

their spouses have not educated, women who perceive their economic situation as bad, do not work in income-generating jobs and women with more than 3 children are significantly more exposed to physical violence $(p<0.05)$. Multivariate logistic regression analysis showed that no school education of women (OR 3.40, 95\% Cl 2.30-5.03), uneducated spouses (OR 6.5I, 95\% Cl 3.39-12.5I), perception of economic status as bad (OR 2.I I, 95\% Cl I.57-2.84), and not working in an income-generating job (OR 2.47, 95\% Cl I.70-3.60) increased the risk of physical violence exposure.

Table 3 gives the distribution of verbal and emotional violence suffered by women according to their demographic characteristics. In terms of verbal/emotional violence, the age of the woman and the age difference with her husband were not seen as significant variables. Similar to the physical violence, women who did not receive school education, perceived her economic status as poor, were not working, and had more than

Table 2. Distribution of physical violence exposed by women according to their demographic characteristics

\begin{tabular}{|c|c|c|c|c|c|}
\hline \multirow[t]{2}{*}{ Demographic characteristics } & $\begin{array}{c}\text { There is physical } \\
\text { violence }\end{array}$ & $\begin{array}{l}\text { No physical } \\
\text { violence }\end{array}$ & \multirow[t]{2}{*}{$\begin{array}{c}\text { Test of } \\
\text { significance }\end{array}$} & \multirow[t]{2}{*}{ OR } & \multirow[t]{2}{*}{ Cl } \\
\hline & $\%$ & $\%$ & & & \\
\hline
\end{tabular}

Age

30 years and under

Over 30 years

Age difference with partner

$\leq 6$

Over 6 years

Education level of woman

No school education

Primary and secondary school

High school and university

Education level of partner

No school education

Primary and secondary school

High school and university

Economic situation perception

Bad

Middle and good

Women's occupation

Not working

Number of children

No children

I child

2 children

3 children and more
Working
117

267

41.9

57.4

288

96

49.2

60.4

297

63

50.8

39.6

$X^{2}=6.220$

$\mathrm{p}=0.013$

0.636

135

68.5

148

51.4

62

31.5

140

48.6

$X^{2}=39.084$

$\mathrm{p}=0.000$

61.0

58

82.9

154

57.0

12

17. 1

43.0

$X^{2}=43.759$

$\mathrm{p}=0.000$

6.519

1.791

57.4

172

42.6

232

216

168

61.4

42.9

136

38.6

224

57.1

$X^{2}=25.434$

2.118

$\mathrm{p}=0.000$

333

56.1

261

43.9

34.0

99

66.0

$X^{2}=23.337$

$\mathrm{p}=0.000$

38

35.8

61

42.4

68

64.2

93

50.3

191

I

83

92

57.6

49.7

$117 \quad 38.0$

$\begin{array}{cl}X^{2}=28.952 & 0.34 I \\ p=0.000 & 0.448 \\ & 0.616\end{array}$

$0.397-0.723$

$0.445-0.909$

2.304-5.035

I.177-2.324

$3.396-12.514$

1.312-2.445

$1.579-2.840$

$1.703-3.602$

* 15 respondents were excluded from the analysis because they did not respond to physical violence questions. OR: Odds ratio; Cl: Confidence interval. 
Table 3. Distribution of verbal / emotional violence exposed by women according to their demographic characteristics

\begin{tabular}{|c|c|c|c|c|c|c|c|}
\hline \multirow[t]{2}{*}{ Demographic characteristics } & \multicolumn{2}{|c|}{$\begin{array}{c}\text { There is } \\
\text { verbal/emotional } \\
\text { violence }\end{array}$} & \multicolumn{2}{|c|}{$\begin{array}{c}\text { No } \\
\text { verbal/emotional } \\
\text { violence }\end{array}$} & \multirow[t]{2}{*}{$\begin{array}{c}\text { Test of } \\
\text { significance }\end{array}$} & \multirow[t]{2}{*}{ OR } & \multirow[t]{2}{*}{$\mathbf{C l}$} \\
\hline & $\mathbf{n}$ & $\%$ & $\mathbf{n}$ & $\%$ & & & \\
\hline \multicolumn{8}{|l|}{ Age } \\
\hline 30 years and under & 232 & 81.4 & 53 & 18.6 & $X^{2}=0.693$ & $* *$ & $* *$ \\
\hline Over 30 years & 392 & 83.8 & 76 & 16.2 & $\mathrm{p}=0.405$ & & \\
\hline \multicolumn{8}{|l|}{ Age difference with partner } \\
\hline$\leq 6$ & 493 & 83.1 & 100 & 16.9 & $X^{2}=0.141$ & $* *$ & $* *$ \\
\hline Over 6 years & 131 & 81.9 & 29 & 18.1 & $\mathrm{p}=0.707$ & & \\
\hline \multicolumn{8}{|l|}{ Education level of woman } \\
\hline No school education & 177 & 88.9 & 22 & II.I & $X^{2}=14.728$ & 2.321 & I.369-3.935 \\
\hline Primary and secondary school & 239 & 83.6 & 47 & 16.4 & $p=0.002$ & 1.467 & $0.959-2.243$ \\
\hline High school and university & 208 & 77.6 & 60 & 22.4 & & 1 & \\
\hline \multicolumn{8}{|l|}{ Education level of partner } \\
\hline No school education & 69 & 97.2 & 2 & 2.8 & $X^{2}=21.630$ & 9.950 & $2.393-41.364$ \\
\hline Primary and secondary school & 236 & 87.1 & 35 & 12.9 & $\mathrm{P}=0.000$ & 1.945 & $1.273-2.972$ \\
\hline High school and university & 319 & 77.6 & 92 & 22.4 & & 1 & \\
\hline \multicolumn{8}{|l|}{ Economic situation perception } \\
\hline Bad & 309 & 87.5 & 44 & 12.5 & $X^{2}=10.195$ & 1.895 & $1.275-2.817$ \\
\hline Middle and good & 315 & 78.8 & 85 & 21.2 & $p=0.001$ & 1 & \\
\hline \multicolumn{8}{|l|}{ Women's occupation } \\
\hline Not working & 517 & 86.0 & 84 & 14.0 & $X^{2}=20.873$ & 2.588 & $1.705-3.930$ \\
\hline Working & 107 & 70.4 & 45 & 29.6 & $p=0.000$ & 1 & \\
\hline \multicolumn{8}{|l|}{ Number of children } \\
\hline No children & 84 & 77.8 & 24 & 22.2 & & $0.47 \mathrm{I}$ & $0.267-0.832$ \\
\hline I child & 115 & 78.2 & 32 & 21.8 & $X^{2}=10.836$ & 0.483 & $0.287-0.814$ \\
\hline 2 children & 150 & 80.6 & 36 & 19.4 & $p=0.013$ & 0.561 & $0.340-0.924$ \\
\hline 3 children and more & 274 & 88.1 & 37 & 11.9 & & 1 & \\
\hline
\end{tabular}

"7 respondents were excluded from the analysis because they did not respond to verbal / emotional violence questions. ${ }^{* *}$ Logistic regression analysis was not performed because it was not significant in the chi-square test. OR: Odds ratio; $\mathrm{Cl}$ : Confidence interval.

3 children were more exposed to verbal/emotional violence $(p<0.05)$. In a multivariate logistic regression analysis, it was found that having no school education of women (OR-2.32I, 95\% Cl I.36-3.93) and having no school education of their spouses (OR 9.95, 95\% Cl 2.393-4l.36) increased the risk of verbal/emotional violence exposure. In the same analysis, it was determined that women's perception of their economic status as bad (OR-I.89, 95\% Cl I.27-2.8I) and not working in an income-generating job (OR-2.58, 95\% Cl I.70-3.93) increased the risk of verbal/emotional violence exposure.

Distribution of sexual violence suffered by women is given in Table 4 according to demographic characteristics. Exposure to sexual violence among the women participating in the study did not make a significant difference by age $(p>0.05)$. However, women with more than 6 years of age difference with their spouses were exposed to more sexual violence $(p<0.05)$. According to other demographic characteristics, women who did not have school education, perceived their socioeconomic status as poor, did not work and had more than 3 children were significantly more exposed to sexual violence $(p<05)$. In a multivariate logistic regression analysis, having no school education of women (OR-2.I7, 95\% Cl I.47-3.20), having no school education of their spouses (OR-4.94, 95\% Cl 2.78-8.77), women's perception of their economic status as bad (OR-2.23, 95\% Cl I.64-3.03) and not working in an income-generating job (OR-I.62, 95\% Cl I.I02.39) increased the risk of sexual violence exposure.

The distribution of the economic violence suffered by women according to demographic characteristics is given in Table 5 . According to this, while the age was not a significant factor 
Table 4. Distribution of sexual violence exposed by women according to their demographic characteristics

\begin{tabular}{|c|c|c|c|c|c|c|c|}
\hline \multirow[t]{2}{*}{ Demographic characteristics } & \multicolumn{2}{|c|}{$\begin{array}{l}\text { There is sexual } \\
\text { violence }\end{array}$} & \multicolumn{2}{|c|}{$\begin{array}{l}\text { No sexual } \\
\text { violence }\end{array}$} & \multirow[t]{2}{*}{$\begin{array}{c}\text { Test of } \\
\text { significance }\end{array}$} & \multirow[t]{2}{*}{ OR } & \multirow[t]{2}{*}{$\mathbf{C l}$} \\
\hline & $\mathbf{n}$ & $\%$ & $\mathbf{n}$ & $\%$ & & & \\
\hline \multicolumn{8}{|l|}{ Age } \\
\hline 30 years and under & 94 & 35.2 & 173 & 64.8 & $X^{2}=3.588$ & $* *$ & ** \\
\hline Over 30 years & 189 & 42.4 & 257 & 57.6 & $\mathrm{p}=0.058$ & $* *$ & $* *$ \\
\hline \multicolumn{8}{|l|}{ Age difference with partner } \\
\hline$\leq 6$ & 207 & 37.0 & 352 & 63.0 & $X^{2}=7.656$ & 1 & \\
\hline Over 6 years & 76 & 49.4 & 78 & 50.6 & $p=0.006$ & 0.604 & $0.421-0.865$ \\
\hline \multicolumn{8}{|l|}{ Education level of woman } \\
\hline No school education & 98 & 52.7 & 88 & 47.3 & $X^{2}=18.065$ & 2.175 & $1.474-3.208$ \\
\hline Primary and secondary school & 100 & 36.2 & 176 & 63.8 & $\mathrm{P}=0.000$ & 1.110 & $0.775-1.588$ \\
\hline High school and university & 85 & 33.9 & 166 & 66.1 & & 1 & \\
\hline \multicolumn{8}{|l|}{ Education level of partner } \\
\hline No school education & 47 & 71.2 & 19 & 28.8 & $X^{2}=34.162$ & 4.947 & $2.789-8.776$ \\
\hline Primary and secondary school & 107 & 41.2 & 153 & 58.8 & $p=0.000$ & 1.399 & $1.011-1.936$ \\
\hline High school and university & 129 & 33.3 & 258 & 66.7 & & 1 & \\
\hline \multicolumn{8}{|l|}{ Economic situation perception } \\
\hline Bad & 168 & 49.7 & 170 & 50.3 & $X^{2}=26.915$ & 2.234 & $1.645-3.034$ \\
\hline Middle and good & 115 & 30.7 & 260 & 69.3 & $p=0.0001$ & 1 & \\
\hline \multicolumn{8}{|l|}{ Women's occupation } \\
\hline Not working & 238 & 42.0 & 329 & 58.0 & $X^{2}=6.034$ & 1.624 & $1.101-2.395$ \\
\hline Working & 45 & 30.8 & 101 & 69.2 & $p=0.014$ & 1 & \\
\hline \multicolumn{8}{|l|}{ Number of children } \\
\hline No children & 34 & 33.3 & 68 & 66.7 & & 0.470 & $0.308-0.718$ \\
\hline I child & 44 & 32.1 & 93 & 67.9 & $X^{2}=23.534$ & 0.451 & $0.304-0.668$ \\
\hline 2 children & 54 & 31.2 & 119 & 68.8 & $p=0.0001$ & 1 & \\
\hline 3 children and more & 150 & 50.0 & 150 & 50.0 & & 0.497 & $0.311-0.794$ \\
\hline
\end{tabular}

"47 respondents were excluded from the analysis because they did not respond to sexual violence questions. "*ogistic regression analysis was not performed because it was not significant in the chi-square test. OR: Odds ratio; $\mathrm{Cl}$ : Confidence interval.

$(p>0.05)$, in a similar manner with other violence types the women, who had more than 6 years of age difference with their spouses, did not have school education, perceived their economic situation as bad, do not work and had more than 3 children, were exposed to economic violence much more $(p<0.05)$. In a multivariate logistic regression analysis, it was found that having no school education of women (OR-3.236, $95 \% \mathrm{Cl} 2.189-4.784)$, having no school education of their spouses (OR-6.780, 95\% Cl 3.58-12.82), women's perception of their economic status as bad (OR-3.06, 95\% Cl 2.26-4.15), and not working (OR-2.15, 95\% Cl I.47-3.15) increase the risk of economic violence exposure.

\section{DISCUSSION}

The concept of violence involves a variety of coercive behaviors to dominate the victim and includes physical, sexual, emotional and economic abuse. ${ }^{[19]}$ One of every two women who participated in our research $(5 \mathrm{I} .5 \%)$ was subjected to physical violence. The type of physical violence most frequently resorted by spouses in our work are; shaking, battering, slapping, punching/kicking, and dragging by hair. Based on Family Violence against Women Survey results of Turkey's $35.5 \%$ of women had been subjected to physical violence. ${ }^{[20]}$ In the same survey, $68.9 \%$ of the women living in the Middle East Anatolian region where Elazig is located were subjected to physical violence by their spouses or men who lived together. Our research findings are above the average of Turkey and are lower than the rate of violence in the Middle East Anatolia region. When we look at the studies conducted abroad, we found that some results have higher rate of physical violence than our research results, there are also studies that have lower. ${ }^{[1-13]}$ These findings show us that violence 
Table 5. Distribution of economic violence exposed by women according to their demographic characteristics

\begin{tabular}{|c|c|c|c|c|c|c|c|}
\hline \multirow[t]{2}{*}{ Demographic characteristics } & \multicolumn{2}{|c|}{$\begin{array}{c}\text { There is economic } \\
\text { violence }\end{array}$} & \multicolumn{2}{|c|}{$\begin{array}{l}\text { No economic } \\
\text { violence }\end{array}$} & \multirow[t]{2}{*}{$\begin{array}{c}\text { Test of } \\
\text { significance }\end{array}$} & \multirow[t]{2}{*}{ OR } & \multirow[t]{2}{*}{$\mathbf{C l}$} \\
\hline & $\mathbf{n}$ & $\%$ & $\mathbf{n}$ & $\%$ & & & \\
\hline \multicolumn{8}{|l|}{ Age } \\
\hline 30 years and under & 120 & 44.3 & $15 \mid$ & 55.7 & $X^{2}=1.896$ & $* *$ & ** \\
\hline Over 30 years & 225 & 49.6 & 229 & 50.4 & $p=0.169$ & $* *$ & ** \\
\hline \multicolumn{8}{|l|}{ Age difference with partner } \\
\hline$\leq 6$ & 260 & 45.5 & 311 & 54.5 & $X^{2}=4.538$ & 1 & \\
\hline Over 6 years & 85 & 55.2 & 69 & 44.8 & $p=0.033$ & 0.679 & $0.475-0.971$ \\
\hline \multicolumn{8}{|l|}{ Education level of woman } \\
\hline No school education & 120 & 63.2 & 70 & 36.8 & $X^{2}=35.966$ & 3.236 & $2.189-4.784$ \\
\hline Primary and secondary school & 136 & 48.9 & 142 & 51.1 & $\mathrm{P}=0.000$ & 1.808 & $1.276-2.56 \mathrm{I}$ \\
\hline High school and university & 89 & 34.6 & 168 & 65.4 & & 1 & \\
\hline \multicolumn{8}{|l|}{ Education level of partner } \\
\hline No school education & 55 & 80.9 & 13 & 19.1 & $X^{2}=46.173$ & 6.780 & $3.584-12.829$ \\
\hline Primary and secondary school & 139 & 52.7 & 125 & 47.3 & $p=0.000$ & 1.782 & I.300-2.444 \\
\hline High school and university & 151 & 38.4 & 242 & 61.6 & & 1 & \\
\hline \multicolumn{8}{|l|}{ Economic situation perception } \\
\hline Bad & 214 & 61.8 & 132 & 38.2 & $X^{2}=53.988$ & 3.069 & $2.267-4.156$ \\
\hline Middle and good & $|3|$ & 34.6 & 248 & 65.4 & $p=0.000$ & 1 & \\
\hline \multicolumn{8}{|l|}{ Women's occupation } \\
\hline Not working & 296 & 51.4 & 280 & 48.6 & $X^{2}=16.249$ & 2.157 & $|.477-3.15|$ \\
\hline Working & 49 & 32.9 & 100 & 67.1 & $p=0.000$ & 1 & \\
\hline \multicolumn{8}{|l|}{ Number of children } \\
\hline No children & 45 & 44.1 & 57 & 55.9 & & & \\
\hline I child & 60 & 42.6 & 81 & 57.4 & $X^{2}=20.042$ & & \\
\hline 2 children & 66 & 37.3 & 111 & 62.7 & $p=0.000$ & 1 & \\
\hline 3 children and more & 173 & 56.9 & 131 & 43.1 & & & \\
\hline
\end{tabular}

"35 respondents were excluded from the analysis because they did not respond to economic violence questions. "*ogistic regression analysis was not performed because it was not significant in the chi-square test. OR: Odds ratio; $\mathrm{Cl}$ : Confidence interval.

against women is an extremely widespread phenomenon all over the world and in cultures, regardless of geographic boundaries and the level of economic development.

In our study, it was found that women who did not receive school education increased their risk of physical violence by 3.40 times. When we look at other studies conducted in Turkey, it is found that illiterate women and women with low level of education are exposed to physical violence much more likewise our study. ${ }^{[21-23]}$ Overseas studies also support the finding that women with lower levels of education are exposed to more physical violence. ${ }^{[24-28]}$ However, in our research it is also seen that violence continues to exist in women whose education level is different. On the basis of this, it is thought that violence culture in the society are effective and that women perceived violence as a part of their lives due to their upbringing styles.
In our study, it was observed that the risk of physical violence increased by $6.5 \mathrm{I}$ times if the spouses of the women had not received school education. Men with lower education levels have resorted more physical violence to their spouses. Our research findings are consistent with literature findings. ${ }^{[23]}$ These results reveal the importance of educating not only women but also men. In parallel with the increase in the level of education of spouses in our research, the rate of violence suffered by women continues to decrease but still remains. It is thought that the level of consciousness of the community is effective for violence persistence.

The fact that a woman works in a job allows her to be economically independent and to leave a violent relationship whenever she wants. The risk of exposure to physical violence in women who did not work increased by 2.47 times in our study. In the study of Dhungel et al.," ${ }^{[29]}$ it has been 
determined that economic dependence of women on their husbands increase the risk of physical violence by 3.04 times and in the study of Fageeh by 1.5 times. ${ }^{[8]}$ In his work Shiraz stated that a woman's work in an income-generating job makes her stronger, enhances her status, thereby reducing the risk of domestic violence and positively affects her life. ${ }^{[30]}$ Anderberg et al. ${ }^{[1]}$ stated in their study that the increase in female unemployment increased domestic abuse.

In our study, women who perceived their economic status as bad were exposed to more physical violence. Surveys reveal that unemployment, economic difficulties and inadequacies cause women to experience violence. ${ }^{[32,33]}$ When studies done abroad are examined; probability of abuse among women with bad socioeconomic status increases, ${ }^{[28]}$ high family income protects against the risk of violence, ${ }^{[34]}$ women in the lower income groups were 7 times more likely to suffer from domestic violence than women in higher income groups. ${ }^{[35]}$ These findings support our study that stated the poor socioeconomic level as an important risk factor for violence against women. Inequality of women's participation in paid employment and decision-making mechanism affects their attainment of economic and social resources in a negative way. There is violence in all income levels, with violence decreasing inversely proportional to the income levels of the families. The high socioeconomic level is thought to have a positive effect on man's view of the woman and on the democratic solution of the domestic problems that may arise.

In our study, eight out of ten women (82.9\%) were exposed to emotional/verbal aggression. The most frequent forms of emotional violence that the spouses were subjected to were cold and hard behavior, mocking, and disdain. According to the CDC, spousal violence often begins with emotional violence, which is followed by physical or sexual violence. ${ }^{[36]}$ There are studies that have lower rates of emotional/verbal violence, ${ }^{[23,37]}$ as well as studies that have higher rates ${ }^{[23]}$ than other studies done at home and abroad. This difference may be due to characteristics, regional and cultural differences of the sampling group. Emotional violence can have very different causes, such as jealousy, the need to keep it under pressure, economic problems. In our study, it was determined that having no school education of women increase the risk to be exposed to emotional/verbal violence 2.32 times, having no school education of their spouses 9.95 times, lower socioeconomic level perception 1.89 times, and not working in a income-generating job 2.58 times. In short, the level of education of women and their spouses, the socio-economic level, the working status of women and the number of children are also contributing factors for emotional violence.

The proportion of women who were exposed to sexual violence in our study was $39.7 \%$. The most common type of sexual violence the spouses have had is sexual intercourse, even though the woman does not want it. Men who see themselves as a focus of power, have a sense of incompe- tence about their masculinity, and the continuing patriarchal structure can have an impact on women's exposure to sexual violence. According to investigation of domestic violence against women in Turkey results 12\% of women in Turkey have been exposed to sexual violence. ${ }^{[10]}$ When we look at other domestic researches; in the study of Yanık et al., ${ }^{[22]}$ $2.9 \%$ of the women were exposed to sexual violence, while in the of Özyurt and Deveci study it was found to be $14.8 \%$. [38] The reason for the differences in these rates may be that sexual violence is not perceived as a form of violence by both the victim and the practitioner, and considered natural and not reported for these reasons. Consideration of sexual violence shown by women's spouses as an expression of love or as a natural consequence of manhood may be thinkable among other reasons. ${ }^{[39]}$ When we look at overseas studies; $58.8 \%$ of women in a study conducted in India were exposed to sexual violence, ${ }^{[40]}$ in a study conducted in Iran, this rate was found as $52.4 \%^{[19]}$ and higher than our research findings. [25] In our study, it was determined that having no school education of women increase the risk to be exposed to sexual violence 2.17 times, having no school education of their spouses 4.94 times, lower socioeconomic level perception 2.23 times, and not working in a income-generating job I.62 times. In a study conducted abroad, it was determined that women and their spouses with low educational level and women who are economically dependent on their husbands are more likely to experience sexual violence and these support our research findings. ${ }^{[29]}$ In another study, women who did not work were found to be at greater risk of sexual violence. ${ }^{[34]}$

In our study, $47.6 \%$ of the women were exposed to economic violence (Table 5). In a study conducted in Iran, $53.4 \%$ of the women were exposed to economic violence. ${ }^{[25]}$ In our study, it was determined that having no education of women increase the risk to be exposed to economic violence 3.23 times, having no education of their spouses 6.78 times, lower socioeconomic level perception 3.06 times, and not working in an income-generating job 2.15 times.

\section{Conclusion}

The types of violence that women who participated in our research were most frequently exposed to verbal/emotional violence, physical violence, economic violence, and sexual violence, respectively. Women who and their spouse had no school education, who perceive their economic status as poor, who do not work in an income-generating job, and who had a number of children 3 or more, were more exposed to physical, verbal/emotional, sexual and economic violence. Violence against women, a problem that arises everywhere in the world, despite policies and practices determined at national and international level, requires a common and determined struggle at a social level with multifaceted, holistic, inclusive plans and policies. All kinds of media organs should be used to raise awareness about violence against women, 
women should be strengthened socially, economically and politically, and studies should be supported in order to increase employment rates and education levels of women.

Ethics Committee Approval: This study was approved by the Firat University Faculty of Medicine Clinical Research Ethics Committee (Approval number: 74529554/17-4474, date: 02.05.2013).

Peer-review: Internally peer-reviewed.

Authorship Contributions: Concept: E.Ç., E.P., A.B.D.; Design: E.Ç., E.P., A.B.D.; Supervision: E.Ç., E.P., A.B.D.; Materials: E.Ç.; Data: E.Ç.; Analysis: E.Ç., E.P., A.B.D.; Literature search: E.Ç., E.P., A.B.D.; Writing: E.Ç., E.P.; Critical revision: E.Ç., E.P.

\section{Conflict of Interest: None declared.}

Financial Disclosure: The authors declared that this study has received no financial support.

\section{REFERENCES}

1. Krug EG, Mercy JA, Dahlberg LL, Zwi AB. The world report on violence and health. Lancet 2002;360:1083-8. [CrossRef]

2. Wells D. Sexual violence interventions: Consideration for humanitarian settings. Forensic Sci Int 2017;276:1-4. [CrossRef]

3. Owen KF, Owen DW. Domestic violence against women. Publications of the Prime Ministry Directorate General on the Status of Women; 2008.

4. Pakis I, Demir F, Bektas G, Altin U, Yildirim S. Evaluation of an approach for those patients who appied to the health-care institution regarding violence against women. Acibadem Univ J Health Sci 2017;2:80-4.

5. Ahmad A, Jaleel A. Prevalence and correlates of violence against women in Nepal: Findings from Nepal Demographic Health Survey, 2011. Adv Appl Sociol 2015;5:119. [CrossRef]

6. Mojab S. The nature of Honor and the universality of killing: feminist pedagogy from early warning signals. theoretical and political approaches to violence in the name of honour. Istanbul: Istanbul Bilgi University Publications; 2006.

7. Al Alyani WS, Alshouibi EN. Dentists awareness and action towards domestic violence patients: A cross-sectional study among dentists in Western Saudi Arabia. Saudi Med J 2017;38:82-8. [CrossRef]

8. Fageeh WM. Factors associated with domestic violence: A cross-sectional survey among women in Jeddah, Saudi Arabia. BMJ Open 2014;4:e004242. [CrossRef]

9. Cortes LF, De Mello Padoin SM, De Paula CC, Vieira LB, Landerdahl $\mathrm{MC}$, et al. Limitations and possibilities on health assessment to women in violence situation. Health 2013;5:45. [CrossRef]

10. Paksoy EN. Health consequences of violence against women. 1. Women's Health Congress: Violence against Women. 20-22 March 2008; 2008.

11. Edwards TA, Houry D, Kemball RS, Harp SE, McNutt LA, Straus H, et al. Stages of change as a correlate of mental health symptoms in abused, low-income African American Women. J Clin Psychol 2006;62:153143. [CrossRef]

12. Ellsberg M, Heise L. Researching violence against women: a practical guide for researchers and activists. Washington, DC: World Health Organization; 2005.

13. Aksakal H, Atasayar M. A qualitative study on the psychological, physiological and sociological consequences of domestic violence on women: International Refereed Social Sciences e-Journal; 2011. p. 1-12.
14. Incecik Y, Kurdak H, Ozcan S, Akpinar E, Saatci E, Bozdemir N. Partner violence and family medicine. Turk J Fam Med Prim Care 2009;3:1-8.

15. Doganavsargil O, Vahip I. Clinical interview method at determine to domestic violence. J Clin Pscys 2007;17:125-36.

16. World Health Organization. Global and regional estimates of violence against women: Prevalence and health effects of intimate partner violence and non-partner sexual violence. Geneva: World Health Organization; 2014. Available from: http://apps.who.int/iris/bitstream/10665/85241/1/WHO_RHR_HRP_13.06_eng.pdf?ua=1. Accessed Oct 22, 2019.

17. Turkey Statistical Institute. Domestic violence statistics for women; 2014. Available from: http://www.tuik.gov.tr/VeriTabanlari.do?ust_ id $=109 \& v t \_i d=31$. Accessed Oct 23, 2019.

18. Sümbüloğlu K, Sümbüloğlu V. Bioistatistic. Ankara: Hatipoglu Publisher; 2016. p. 218-38.

19. Chireshe E. Christian women's experiences of domestic violence in Zimbabwe. Affilia 2015;30:380-94. [CrossRef]

20. HUIPS. Research on against women in turkey domestic violence. Turkey's General Directorate on the Status of Women. Ankara: Republic of Turkey Ministry of Family and Social Policies; 2015.

21. Tetikcok R, Ozer E, Cakir L, Enginyurt O. Iscanli MD, Cankaya S, et al. Violence towards women is a public health problem. J Forensic Legal Med 2016;44:150-7. [CrossRef]

22. Yanık A, Hanbaba Z, Soygur S, Ayaltı B, Doğan M. Evaluation of violent behavior agaist women: evidence from Turkey. Electron J Vocat Coll 2014;4:104-11.

23. Tokuc B, Ekuklu G, Avcioglu S. Domestic violence against married women in Edirne. J Interpers Violence 2010;25:832-47. [CrossRef]

24. Chowdhury SR, Bohara AK, Horn BP. Balance of power, domestic violence, and health injuries: Evidence from demographic and health survey of Nepal. World Dev 2018;102:18-29. [CrossRef]

25. Zarei M, Rasolabadi M, Gharibi F, Seidi J. The prevalence of violence against women and some related factors in Sanandaj city (Iran) in 2015. Electron Phys 2017;9:5746-53. [CrossRef]

26. Semahegn A, Mengistie B. Domestic violence against women and associated factors in Ethiopia; systematic review. Reprod Health 2015;12:112. [CrossRef]

27. Doku DT, Asante KO. Women's approval of domestic physical violence against wives: Analysis of the Ghana demographic and health survey. BMC Womens Health 2015;15:120.

28. Cruz GV, Domingos L, Sabune A. The characteristics of the violence against women in Mozambique. Health 2014;6:1589-601. [CrossRef]

29. Dhungel S, Dhungel P, Dhital SR, Stock C. Is economic dependence on the husband a risk factor for intimate partner violence against female factory workers in Nepal? BMC Womens Health 2017;17:82. [CrossRef]

30. Shiraz MS. The impact of education and occupation on domestic violence in Saudi Arabia. Int J Soc Welfare 2016;25:339-46. [CrossRef]

31. Anderberg D, Rainer H, Wadsworth J. Wilson T. Unemployment and domestic violence: Theory and evidence. Econ J 2016;126:1947-79. [CrossRef]

32. Aşkın EO, Aşkın U. Kadına yönelik aile içi şiddet ve yoksulluk ilişkisi: aile içi şiddet mağduru kadinlar üzerine bir araştirma. Kapadokya Akademik Bakış 2017;1:16-37.

33. Çötok NA. Toplumsal cinsiyet rolü dâhilinde kadına şiddet olgusuna karşı kadın algısı Int J Soc Sci Educ Res 2015;1:778-90.

34. Babu BV, Kar SK. Domestic violence in Eastern India: Factors associated with victimization and perpetration. Public Health 2010;124:136-48.

35. Rand M, Rennison C. How much violence against women is there? Violence against women and family violence. Dev Res Pract Policy 
2004;8:1-11

36. Centers for Disease Control and Prevention. Understanding Intimate Partner Violence. Fact Sheet. Atlanta, Georgia: Centers for Disease Control and Prevention; 2009. Available from: http://www.cdc.gov/violence prevention. Accessed Oct 29, 2019.

37. Sheikhbardsiri H, Raeisi A, Khademipour G. Domestic violence against women working in four educational hospitals in Iran. J Interpers Violence 2017;14:1-15.

38. Özyurt BC, Deveci A. The relationship between domestic violence and the prevalence of depressive symptoms in married women between 15 and 49 years of age in a rural area of Manisa, Turkey. Turk J Psychiatry 2010;21:10-6.

39. Öntaş C, Doğru ES. Lisede okuyan kız öğrencilerin kadına yönelik şiddete ilişkin algıları: Niteliksel bir çalşma. Hacettepe Univ J Econ Adm Sci 2015;26:45-63.

40. Pal J, Mullick TH, Ahmad S. Yadav AK. Domestic Violence against women- an unsolved 1ssue: A community based study in an urban slum of Kolkata, India. J Clin Diagn Res 2017;11:LC01-4. [CrossRef]

\section{ORIJINAL ÇALIŞMA - ÖZ}

\section{Evli kadınların eş şiddetine maruz kalma durumları: Türkiye’nin Doğusunda toplum tabanlı bir çalışma}

\section{Dr. Evrim Çelebi, ${ }^{1}$ Dr. Edibe Pirincci, ${ }^{2}$ Dr. Ayşe Birsen Durmuş ${ }^{3}$}

${ }^{1}$ Fırat Üniversitesi Sağlık Bilimleri Fakültesi, Ebelik Bölümü, Elazığ

${ }^{2}$ Fırat Üniversitesi Tıp Fakültesi, Halk Sağlığı Anabilim Dalı, Elazığ

${ }^{3}$ Fırat Üniversitesi Sağlık Hizmetleri Meslek Yüksekokulu, Elazığ

AMAÇ: Kadına yönelik şiddet, kadınları eşitlik, güvenlik, haysiyet, öz değer ve temel özgürlüklerden yararlanma haklarından yoksun bırakan, kadınları değersizleştiren; kadınları erkeklere göre daha aşağı toplumsal bir durumda var olmaya zorlayan en önemli sosyal oluşlardandır ve sağlıklı toplumların oluşmasında önemli bir engel oluşturmaktadır. Bu araştırma, Türkiye’nin Doğusunda yer alan Elazığ il merkezinde yaşayan 15 yaş ve üzeri evli kadınların eş şiddetine maruz kalma durumlarını belirlemek amacıyla yapıldı.

GEREÇ VE YÖNTEM: Elazığ il merkezinde bulunan tüm aile sağlık merkezlerine gidilerek ilgili kayıtlardan sistematik örnekleme yapılarak 792 evli kadın seçildi. Veri toplama aracı olarak anket formu kullanıldı. Anket formu iki bölümden oluşmaktaydı. İlk bölümde katılımcıların yaşı, cinsiyeti, eğitim düzeyi, mesleği gibi demografik özelliklere ilişkin sorulara yer verilirken, ikinci bölümde şiddete maruz kalma durumlarını belirlemeye yönelik sorular soruldu. Anketler ev ziyaretleri yapılarak yüz yüze görüşsme tekniği kullanılarak dolduruldu.

BULGULAR: Araştırmaya katılan kadınların \%5।.5'i fiziksel şiddete, \%82.9'u sözel/duygusal şiddete, \%39.7'si cinsel şiddete, \%47.6'sı ekonomik şiddete maruz kalmıştı. Kadının ve eşinin eğitim düzeyinin düşüklüğü, ailenin ekonomik durumunun kötü olarak algılanması, kadının gelir getiren bir işte çalışmıyor olması eşi tarafından hem fiziksel şiddet hem de ekonomik şiddet görmesinin önemli bir faktör olabileceği bulundu.

TARTIŞMA: Elazığ il merkezinde yaşayan evli kadınlarda eş şiddeti maruziyeti yüksektir. Sorunun bireysel, ailesel toplumsal düzeylerde çözümüne yönelik eğitim ve hizmet sunulmalıdır.

Anahtar sözcükler: cinsel şiddet; duygusal şiddet; ekonomik şiddet; eş şiddeti; fiziksel şiddet.

Ulus Travma Acil Cerrahi Derg 2022;28(I):69-77 doi: 10.14744/tjtes.2020.470I2 